\title{
Occupational stress among library personnel in public universities in Nigeria
}

\author{
Omobola Olufunke Adewoyin \\ Nigerian Institute of Medical Research \\ Lagos, Nigeria \\ Maria Ehioghae \\ Babcock University Medical Library \\ Ilishan Remo, Ogun State, Nigeria \\ Joseph Olubunmi Olorunsaye \\ Kenneth Dike Library \\ University of Ibadan, Nigeria
}

\begin{abstract}
Occupational stress, which is stress experienced by employees at the workplace, is increasingly becoming a challenge. It is often the case that when employees are confronted with work demands and pressures beyond their knowledge and abilities, stress may be the outcome. Due to their role expectations, paraprofessional and professional librarians are susceptible to occupational stress which could lead to a decreasing commitment to the organization. The study adopted a survey research design to investigate occupational stress among paraprofessional and professional librarians in public universities in South-West, Nigeria. Total enumeration was used to cover all professional and paraprofessional librarians in the study area. Out of the 280 copies of questionnaire administered, $268(95.7 \%)$ were retrieved for analysis. The findings revealed that male library personnel experience more stress in public universities than their female counterpart. Specifically, the precursors to stress among library personnel, with high mean scores, include sourcing of funds for career development $(\bar{x}=3.79)$, the quest for promotion $(\bar{x}=3.41)$, excessive workloads ( $\bar{x}=3.49)$, and broken interpersonal relationships with management ( $\bar{x}=3.09)$. The study, therefore, recommends equity in the sharing of responsibilities between the male and female genders to partly reduce pressure due to excessive workloads. Also, library personnel should have access to research funds to facility upward mobility in their career. In addition, interpersonal relationship workshops should be regularly conducted for allcadres of staff to promote team spirit.
\end{abstract}

Keywords: Library personnel, public universities, stress, workloads, inter-personal relationships

\section{Introduction}

Library personnel in university libraries play a crucial role in satisfying the information needs of the university community. They are charged with a wide range of tasks which include acquiring, storing, organizing and disseminating information, providing information resources required to support the learning, teaching, and research needs of their universities. Also, they are intermediaries between the information resources and users; they are expected to provide timely and quality information resources to their users.

However, one of the factors that could probably hinder library personnel in the provision of quality information services to their users is stress. Stress has become a major problem in today's challenging and turbulent working environment (Ahmad \& Roslan, 2016).Okoro (2008) asserted that stress is not only an unpleasant result of emotional conflict but also one of the major factors contributing to low productivity among a nation's workforce. Stress that is experienced by employees at the workplace 
Omobola Olufunke Adewoyin, Maria Ehioghae and Joseph Olubunmi Olorunsaye: Occupational stress among library personnel in public universities in Nigeria

is called occupational stress. Occupational stress is a major basis of decreasing employee commitment towards the organization.

Occupational stress is the response people may have when presented with work demands and pressures that are not matched to their knowledge and abilities and which challenge the ability to cope (WHO, 2003). Occupational stress, job stress, and work stress are terms that are often used interchangeably. Occupational stress is considered a psychological factor which will emerge due to the given job-related activities for employees (Siahaan, 2017). Ella, Asuquo, Akpan-Idiok, and Ijabula (2016) opine that manifestations of job stress among others include illness, muscular tensions and ache, tightness in the chest, high blood pressure, heart problems, snapping and arguing with others, aggressive or hostile behavior, blaming others or administration for tension, absenteeism, and high staff job turnover.

Although library personnel in university libraries play a key role in information provision and dissemination, studies and personal observation show they face several challenges. Aderibigbe and Farouk (2017)identified factors such as irregular power supply, low patronage, inadequate infrastructures like photocopiers, computers, air conditioners, unavailability of staff, low computer literacy among staff, limited media access as some of the challenges facing the provision of quality library and information services. This study investigated occupational stress among library personnel in public universities in South-West, Nigeria.

\section{Objective of the study}

The study investigated occupational stress among library personnel in public universities in South-West, Nigeria. The specific objectives of this study were to:

1. determine the level of occupational stress among library personnel in public universities in South-West, Nigeria;

2. identify factors associated with occupational stress among library personnel in public universities in South-West, Nigeria; and

3. examine factors associated with occupational stress indicators among library personnel in public universities in South-West, Nigeria.

\section{Research questions}

The research questions that guided the study are:

1. What is the level of occupational stress among library personnel in public universities in South-West, Nigeria?

2. What are the factors associated with occupational stress among library personnel in public universities in South-West, Nigeria?

3. What are the factors associated with occupational stress indicators among library personnel in public universities in South-West, Nigeria?

\section{Scope of the study}

The study investigated occupational stress among library personnel in public universities in the South-West, Nigeria. This study covered the paraprofessional and staff working in the federal and state university libraries in the Southwestern Nigeria. The choice of public universities was informed by the fact that these universities have the highest concentration of library personnel in Nigeria. The study covered mostly the library personnel of the main campuses of the universities.

Library and Information Perspectives and Research, Volume 2 Number 1, 2020 
Omobola Olufunke Adewoyin, Maria Ehioghae and Joseph Olubunmi Olorunsaye: Occupational stress among library personnel in public universities in Nigeria

\section{Literature review}

Arogundade and Onabanjo (2013)observed that stress is a term that is widely used in everyday life and it is globally acknowledged as a major challenge to workers' health and the health of an organization. Bhatti, Bhatti, Akram, Hashim, Akram, and Akram (2016) defined job stress as the harmful physical and emotional responses that happen when the requirements of the job do not match the competences, resources, or needs of the worker. Similarly, job stress may be conceptualized as a situation where employees' skills, knowledge, and abilities do not match with organizational requirements (Bhatti et al. 2016).Occupational stress has a negative effect on a person's psychological and physical health as well as an organization's effectiveness (Divakar,2015).

Stress is often made worse when employees feel that they have no support from higher authority and colleagues and find it difficult to have control over work processes(Divakar,2015). Joseph (2013) opines that stress at work is seen as one of the major psychosocial risks of work. In other words, work-related stress is one of the problems confronting employees and is of great concern to employees, employers, and psychologists. It also a precursor to employees' complaints and increased illhealth, accidents, and incidents reports (Sampson \& Akyeampong, 2014).

Stress in the library environment is not good for university libraries as it leads to a decrease in the quality of service delivery and job performance (Dina, 2016). Dina (2016) found that a professional librarian's quality of service in terms of job performance in relation to their job demand and expectation can be affected as a result of enormous stress and that professional librarians who engage in other activities aside their primary assignment for which they were employed are more prone to stress than the others, thereby affecting their job performance negatively. It has been noted that many workers in Nigeria are confronted with many stress factors to cope with or managed (Ajala, 2011). Significantly, occupational stress is one of the factors influencing the physical and mental health of employees (Ahmad \& Roslan, 2016). Indeed, occupational stress can cause unusual and dysfunctional behavior at work and contributes to poor physical and mental health, thereby putting employees' health and organizational success at risk (Ikonne, 2015).

Oghenetega, Ejedafiru and Rabiu (2014) carried out a comparative study of job stress among teaching staff of the library and information science in higher institutions in Nigeria. The objectives of the study were to determine the level of occupational stress in these institutions, to find out the causes of job stress among lecturers, determine the negative impact of job stress on the academic staff of libraries, and to proffer solutions to the increasingly challenging situation. The results revealed that job stress is very high in academic libraries and has made negative impacts on their health and families. The causes of job stress in these institutions are teaching of too many courses, incessant strike actions, poor remuneration, fear of being laid off overtime, excess working hours, too many administrative duties, a high population of students' thesis or project supervision, publish or perish syndrome, challenges of information technology and frequent meetings and others.

Technostress is caused by different factors during the continuous process of using information technologies in carrying out functions that initially were done

Library and Information Perspectives and Research, Volume 2 Number 1, 2020 
Omobola Olufunke Adewoyin, Maria Ehioghae and Joseph Olubunmi Olorunsaye: Occupational stress among library personnel in public universities in Nigeria

manually (Isiakpona \& Adebayo, 2011). Workers who are stressed are more likely to be unhealthy, poorly motivated, less productive and less safe at work (Leka, Griffiths \& Cox, 2003). Work-related stress is the response people may have when presented with work demands and pressures that are not matched to their knowledge and abilities and which challenge their ability to cope (Leka, Griffiths\& Cox,2003). Isiakpona and Adebayo (2011) examined the impact of technostress on librarians. The study found out that sitting positions, slow internet network among others are causes of technostress.

\section{Theoretical framework}

The theory that guided this study was the person-environment (P-E) fit theory. The P-E fit theory was developed by French, Rodgers and Cobb in 1974. Cooper, Deweand O'Driscoll (2001) cited by Akinmayowa (2014) asserted that the P-E fit theory is based on the premise that stress does not arise from a person or the work environment separately, but rather from the interrelationship between stressors in the work environment, the individual's perception of the work situation and his or her subjective responses. According to them, the individual would adjudge the work situation to be stressful when he or she perceives an incompatibility or a lack of fit with the work environment. Cable and DeRue (2002) operationalized P-E fit theory as a three-factor model, comprising personorganization fit (P-O fit), need-supplies fit (N$S$ fit), and demands-abilities fit (D-A fit). According to them, when employees experience $\mathrm{P}-\mathrm{O}$ fit, they feel attached to the organization's mission, put organizational benefits above personal benefits, and find it difficult to leave the organization. N-S fit denotes the correspondence between job rewards and the services provided by the employee while D-A fit refers to the similarity between job demands and the possessed abilities of employees (Cable \& DeRue, 2002).

\section{Methods}

The study adopteda survey research design. The population of the study comprised of the library personnel in the public universities in South-West, Nigeria. As one of the six geopolitical zones in Nigeria, South-Westis made up of six states namely Lagos, Ondo, Osun, Ogun, Ekiti, Oyo states. The public universities in the zone are Federal University of Agriculture, Abeokuta, Federal University, Oye-Ekiti, University of Lagos, University of Ibadan, Federal University of Technology, Akure, and Obafemi Awolowo University, IleIfe Ekiti State University,Ladoke Akintola University of Technology, Ogbomoso,Olabisi Onabanjo University, Ago Iwoye,Lagos State University, Ojo,Tai Solarin University of Education, Ijebu Ode,Osun State University Osogbo,Ondo State University of Medical Sciences, Oyo State Technical University Ibadan.

Total enumeration was used for the entire library personnel in the public universities, South-West, Nigeria. The research instrument used for data collection was a questionnaire. Out of the 280 copies of questionnaire administered to respondents, 268 (representing 95.7\% of the respondents) were retrieved for analysis, using descriptive and inferential statistics such as frequency, percentages, mean and standard deviation.

\section{Findings}

The respondents' demographic information are shown in Table 1. 
Omobola Olufunke Adewoyin, Maria Ehioghae and Joseph Olubunmi Olorunsaye: Occupational stress among library personnel in public universities in Nigeria

Table 1: Respondents' demographic information

\begin{tabular}{|c|c|c|}
\hline 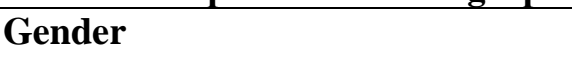 & Frequency & Percentage \\
\hline Male & 131 & 48.9 \\
\hline Female & 128 & 47.8 \\
\hline Missing value & 09 & 3.4 \\
\hline Total & 268 & 100.0 \\
\hline Age range & Frequency & Percentage \\
\hline $20-30 y r s$ & 17 & 6.3 \\
\hline $31-40 y r s$ & 80 & 29.9 \\
\hline $41-50 y r s$ & 125 & 46.6 \\
\hline Above 50yrs & 31 & 11.6 \\
\hline Missing value & 15 & 5.6 \\
\hline Total & 268 & 100.0 \\
\hline Section & Frequency & Percentage \\
\hline Serials & 28 & $10.4 \%$ \\
\hline Acquisitions & 23 & $8.6 \%$ \\
\hline Circulation & 53 & $19.8 \%$ \\
\hline Technical services & 73 & $27.2 \%$ \\
\hline Reader services & 30 & $11.2 \%$ \\
\hline References & 17 & $6.3 \%$ \\
\hline Missing value & 44 & $16.4 \%$ \\
\hline Total & 268 & 100.0 \\
\hline Work experience & Frequency & Percentage \\
\hline $1-5$ years & 31 & 11.6 \\
\hline $6-10$ years & 67 & 25.0 \\
\hline $11-15$ years & 63 & 23.5 \\
\hline $16-20$ years & 48 & 17.9 \\
\hline Over 20 years & 47 & 17.5 \\
\hline Missing value & 12 & 4.5 \\
\hline Total & 268 & 100.0 \\
\hline Highest educational qualification & Frequency & Percentage \\
\hline ND/NCE & 42 & 15.7 \\
\hline HND/B.Sc/BLS & 95 & 35.4 \\
\hline PGD/Masters & 79 & 29.5 \\
\hline $\mathrm{PhD}$ & 30 & 11.2 \\
\hline Missing value & 22 & 8.2 \\
\hline Total & 268 & 100.0 \\
\hline Designation & Frequency & Percentage \\
\hline Professional librarians & 132 & 54.5 \\
\hline Para-professional librarians & 110 & 45.5 \\
\hline Total & 268 & 100.0 \\
\hline Marital Status & Frequency & Percentage \\
\hline Married & 216 & 80.6 \\
\hline Single & 23 & 8.6 \\
\hline Missing value & 29 & 10.8 \\
\hline Total & 268 & 100.0 \\
\hline
\end{tabular}

Library and Information Perspectives and Research, Volume 2 Number 1, 2020 
Omobola Olufunke Adewoyin, Maria Ehioghae and Joseph Olubunmi Olorunsaye: Occupational stress among library personnel in public universities in Nigeria

The results of the study are shown in Table 1. One hundred and thirty-one (48.9\%) respondents were males, while $128(47.8 \%)$ were females. This finding implies that there were more male library personnel in public universities in South-West, Nigeria. The table also showed that there were more respondents in the age brackets of 41-50 years $(46.6 \%)$ than any other age group. This suggests that the profession is probably dominated by middle-aged people which could be categorized as the age of active service. The majority of the library personnel $(27.2 \%)$ worked in the technical section of the library. This could suggest that a higher priority was given to the technical department of the library during recruitment and selection into library sections. Sixty percent of librarians had 15 years of experience or less. This implies that library personnel in public universities in South-West, Nigeria are likely to have a good understanding of operations in the library and provide reliable information that would help lead to the achievement of the objectives of this study. Thirty-five percent of library personnel were HND/BSc/BLS holders. This indicates that for many of the respondents there is still room to acquire more academic qualifications to enhance their professionalism on the job.

One hundred and thirty-two (54.5\%) of the respondents were professional librarians, while $110(45.5 \%)$ respondents were paraprofessional librarians. This finding could imply that library personnel in public universities in South-West, Nigeria, were people with diverse current positions in library cadre with a good number of them holding to the position of the professionals. Lastly, $216(80.6 \%)$ respondents were married, while $23(8.6 \%)$ were single. This means that there were more married respondents than singles. The large number of married people may also suggest that library personnel are responsible enough to take care of themselves and display a sense of maturity in the workplace.

Research question one: What is the level of occupational stress among library personnel in public universities in South-West, Nigeria?

The data in Table 2 provide answer to this question. 
Omobola Olufunke Adewoyin, Maria Ehioghae and Joseph Olubunmi Olorunsaye: Occupational stress among library personnel in public universities in Nigeria

Table 2: Level of occupational stress among the library personnel

\begin{tabular}{|c|c|c|c|c|c|c|}
\hline $\begin{array}{l}\text { Research and career } \\
\text { development stress }\end{array}$ & $\begin{array}{l}\text { Very } \\
\text { high } \\
\text { stress }\end{array}$ & $\begin{array}{l}\text { High } \\
\text { stress }\end{array}$ & $\begin{array}{l}\text { Moderate } \\
\text { stress }\end{array}$ & $\begin{array}{l}\text { Low } \\
\text { stress }\end{array}$ & No stress & Mean \\
\hline $\begin{array}{l}\text { Sourcing of funds for career } \\
\text { development }\end{array}$ & 19.1(49) & $31.1(80)$ & $34.6(89)$ & $10.9(28)$ & $3.5(9)$ & 3.79 \\
\hline $\begin{array}{l}\text { Sourcing for research } \\
\text { funds/grants }\end{array}$ & $22.5(57)$ & $24.9(63)$ & $31.6(80)$ & $16.6(42)$ & $4.0(10)$ & 3.57 \\
\hline $\begin{array}{l}\text { Advancement/promotion } \\
\text { criteria }\end{array}$ & $13.6(35)$ & $31.8(82)$ & $41.9(108)$ & $10.5(27)$ & $2.3(6)$ & 3.44 \\
\hline $\begin{array}{l}\text { Having the required publications } \\
\text { for promotion }\end{array}$ & $15.0(38)$ & $34.8(83)$ & $32.8(83)$ & $10.7(27)$ & $6.7(17)$ & 3.41 \\
\hline $\begin{array}{l}\text { Obtaining research/conference } \\
\text { incentives }\end{array}$ & $17.1(44)$ & $30.4(78)$ & $33.9(87)$ & $12.8(33)$ & $5.8(15)$ & 3.40 \\
\hline $\begin{array}{l}\text { Linkage to other professionals } \\
\text { in my research discipline }\end{array}$ & $13.7(34)$ & $33.5(83)$ & $31.5(78)$ & $17.7(44)$ & $3.6(9)$ & 3.36 \\
\hline $\begin{array}{l}\text { Linkages to avenues of } \\
\text { professional development }\end{array}$ & $9.6(25)$ & $31.2(81)$ & $43.8(114)$ & $11.5(30)$ & $3.8(10)$ & 3.31 \\
\hline Publication of finished articles & $11.0(28)$ & $32.9(84)$ & $34.5(88)$ & $16.5(42)$ & $5.6(13)$ & 3.28 \\
\hline $\begin{array}{l}\text { Access to relevant literatures } \\
\text { Group Mean }=\mathbf{3 . 4 3}\end{array}$ & $13.6(35)$ & $27.6(71)$ & $36.6(94)$ & $15.6(40)$ & $6.6(17)$ & 3.26 \\
\hline $\begin{array}{l}\text { Academic workload stress } \\
\text { Work demands }\end{array}$ & $15.7(41)$ & $\begin{array}{l}31.0 \\
(81)\end{array}$ & $\begin{array}{r}42.5 \\
(111)\end{array}$ & $7.7(20)$ & $3.1(8)$ & 3.49 \\
\hline $\begin{array}{l}\text { State of office } \\
\text { accommodation/facilities } \\
\text { Group Mean = 3.38 }\end{array}$ & $8.9(23)$ & $30.9(80)$ & $\begin{array}{c}44.8 \\
(116)\end{array}$ & $\begin{array}{l}10.4 \\
(27)\end{array}$ & $5.0(4.9)$ & 3.28 \\
\hline Administrative related stress & & & & & & \\
\hline $\begin{array}{l}\text { Leadership behavior of } \\
\text { university executives }\end{array}$ & $10.8(28)$ & $30.0(78)$ & $36.5(95)$ & $17.7(46)$ & $5.0(13)$ & 3.24 \\
\hline $\begin{array}{l}\text { Administrative behavior of } \\
\text { departmental heads }\end{array}$ & 11.1(29) & $30.9(81)$ & $33.2(87)$ & $16.8(44)$ & $8.0(21)$ & 3.20 \\
\hline $\begin{array}{l}\text { Participation in institutional } \\
\text { administration } \\
\text { Group Mean = } \mathbf{3 . 1}\end{array}$ & $10.7(28)$ & $25.7(67)$ & $37.5(98)$ & $21.1(55)$ & $5.0(13)$ & 3.16 \\
\hline $\begin{array}{l}\text { Interpersonal relationship } \\
\text { stress }\end{array}$ & & & & & & \\
\hline $\begin{array}{l}\text { Relationship with university } \\
\text { management }\end{array}$ & $13.3(34)$ & 27.1(69) & $27.5(70)$ & 19.2(49) & $12.9(33)$ & 3.09 \\
\hline $\begin{array}{l}\text { Relationship with heads of } \\
\text { departments }\end{array}$ & $14.2(37)$ & $26.4(69)$ & $23.0(60)$ & $19.5(51)$ & $16.9(44)$ & 3.02 \\
\hline Relationship with students & $14.5(38)$ & & $24.8(65)$ & & $18.7(49)$ & 3.02 \\
\hline
\end{tabular}

Library and Information Perspectives and Research, Volume 2 Number 1, 2020 
Omobola Olufunke Adewoyin, Maria Ehioghae and Joseph Olubunmi Olorunsaye: Occupational stress among library personnel in public universities in Nigeria

$\begin{array}{lccllll} & & 26.0(68) & & 16.0(42) & & \\ \text { Relationship with colleagues } & 15.3(40) & & 22.2(58) & 19.5 & 18.8(49) & 2.98 \\ & & 24.1(63) & & (51) & & \\ \begin{array}{l}\text { Relationship with non-teaching } \\ \text { staff }\end{array} & 14.7(38) & & 23.6(61) & & 19.4(50) & 2.94 \\ & & 22.9(61) & & 19.4(50) & & \end{array}$

\section{Group Mean = 3.0}

Grand Mean $=3.26$

Decision rule: $1-1.49=$ very low level; $1.5-2.49=$ low level; $2.5-3.49=$ moderate level; $3.5-4.49=$ high level; $4.5-5.0=$ very high level. The cut-off mean is 3.0. The cut-off mean of 3.0 is calculated as $(5+4+3+2+1) / 5=15 / 5=3.0$

The result of Table 2 grand mean score of 3.26 shows that the level of occupational stress among library personnel in public universities in South-West, Nigeria, was very high. This finding suggests that a high level of stress could affect librarians' productivity on the job if not well managed. Occupational stress was divided into four dimensions namely research and career development, academic workload, administrative, and interpersonal relationships. Research and career development made the largest contribution to the high level of occupational stress with a group mean score of 3.43. This finding suggests that career development puts immense strain on library personnel on the job than other factors. The academic workload with a grand mean score of 3.38 which was another indicator of occupational stress was also high. This implies that working in the library appears to be highly demanding and puts a strain on library personnel. Administrative related stress was considered high (mean=3.1) and mostly emanated from the leadership behavior of university executives (mean=3.24). This suggests the importance of flexible and democratic leadership participation in leading library employees towards achieving organizational objectives.

Lastly, interpersonal relationship stress had the lowest contribution to occupational stress among the librarians with a high mean score of 3.0. Specifically, librarians perceived their relationship with university management $($ mean=3.09) to be highly stressful whilethe relationship with nonteaching staff $($ mean=2.94) was also considered highly stressful, even though this was considered to be the lowest under interpersonal relationship stress measurement. It is clear from this finding that employees to employees relationships might not be palatable in public university libraries in South-West, Nigeria.

Research question two: What are the factors associated with occupational stress among library personnel in public universities in South-West, Nigeria?

Analysis of factors associated with occupational stress among library personnel in public universities in South-West, Nigeria, is presented in Tables 3-7 this section. 
Omobola Olufunke Adewoyin, Maria Ehioghae and Joseph Olubunmi Olorunsaye: Occupational stress among library personnel in public universities in Nigeria

Table 3: Poisson regression analysis of factors associated with occupational stress

\begin{tabular}{|c|c|c|c|c|c|}
\hline Predictors & Categories & $P$ & $\begin{array}{l}\text { Odds } \\
\text { Ratio } \\
\text { (OR) }\end{array}$ & L-R Stat & $\mathbf{p}$ \\
\hline & (Intercept) & 0.000 & 53.293 & & \\
\hline University type & $\begin{array}{l}\text { Federal } \\
\text { State }\end{array}$ & 0.110 & 1.035 & & \\
\hline \multirow[t]{2}{*}{ Gender } & $\begin{array}{l}\text { Male } \\
\text { Female }\end{array}$ & $0.000 *$ & 1.112 & & \\
\hline & Serials & & 1.130 & & \\
\hline \multirow[t]{5}{*}{ Section } & Acquisitions & & 1.080 & & \\
\hline & Circulation & 0.200 & 1.091 & & \\
\hline & Technical services & & 1.105 & & \\
\hline & Reader services & & 1.109 & & \\
\hline & References & & & 57.008 & 0.005 \\
\hline \multirow{4}{*}{$\begin{array}{l}\text { Highest educational } \\
\text { qualification }\end{array}$} & $\mathrm{ND} / \mathrm{NCE}$ & & 0.902 & & \\
\hline & $\mathrm{HND} / \mathrm{BSc} / \mathrm{BLS}$ & $0.014 *$ & 0.975 & & \\
\hline & PGD/Masters & & 0.939 & & \\
\hline & $\mathrm{PhD}$ & & & & \\
\hline Designation & $\begin{array}{l}\text { Professional librarians } \\
\text { Para-professional }\end{array}$ & $0.047 *$ & 1.053 & & \\
\hline Marital Status & $\begin{array}{l}\text { Married } \\
\text { Single }\end{array}$ & 0.649 & 1.018 & & \\
\hline
\end{tabular}

DEPENDENT VARIABLE: Occupational stress

PREDICTORS: University type, gender, section, highest educational qualification, Designation, marital status

REFERENCE CATEGORIES: State, Female, References, PhD, Para-professional and Single

Source: Research Output (2020)

Factors associated with occupational stress among library personnel in public universities in South-West, Nigeria, were presented in Table 3. The finding revealed that occupational stress was experienced more among male librarians (O.R=1.035, $p<0.05)$ than their female counterparts at a significant level of $5 \%$. By implication, gender is significantly associated with occupational stress among library personnel in public universities in South-West, Nigeria. Furthermore, the result also showed that librarians with the following degrees: ND/NCE (O.R=0.902), HND/B.Sc/BLS (O.R=0.975) and PGD/Masters (O.R=0.939) experienced less stress than their colleagues with $\mathrm{PhD}$. certificates at $5 \%$ level of significance. This implies that educational status is a significant predictor of occupational stress among library personnel in public universities in South-West, Nigeria. More so, professional librarians $(\mathrm{O} . \mathrm{R}=1.053, p<0.05)$ were more likely to experience higher levels of occupational stress than non-professional librarians at 5\% level of significance. By implication, professional designation contributes to occupational stress in public libraries. On the other hand, university type $(p>0.05)$, librarian section $(p>0.05)$ and marital status $(p>0.05)$ did not predict occupational stress among the librarians. The L-R Stat value of $57.008(\mathrm{p}<0.05)$ established the usefulness of the Poisson regression model in estimating the influence of demographic factors on occupational stress among librarians in public libraries. 
Omobola Olufunke Adewoyin, Maria Ehioghae and Joseph Olubunmi Olorunsaye: Occupational stress among library personnel in public universities in Nigeria

Research question three: What are the indicators among library personnel in public factors associated with occupational stress universities in South-West, Nigeria?

\begin{tabular}{|c|c|c|c|c|c|}
\hline Predictors & Categories & $p$ & $\begin{array}{l}\text { Odds } \\
\text { Ratio }\end{array}$ & LR Stat & $\mathbf{P}$ \\
\hline & (Intercept) & 0.000 & 6.995 & & \\
\hline University type & $\begin{array}{l}\text { Federal } \\
\text { State }\end{array}$ & 0.801 & 1.016 & & \\
\hline \multirow[t]{2}{*}{ Gender } & $\begin{array}{l}\text { Male } \\
\text { Female }\end{array}$ & $0.021 *$ & 1.157 & & \\
\hline & Serials & & 0.779 & & \\
\hline \multirow[t]{5}{*}{ Section } & Acquisitions & & 0.777 & & \\
\hline & Circulation & 0.963 & 0.775 & & \\
\hline & Technical services & & 0.791 & & \\
\hline & Reader services & & 0.838 & 8.625 & 0.735 \\
\hline & References & & & & \\
\hline \multirow{4}{*}{$\begin{array}{l}\text { Highest educational } \\
\text { qualification }\end{array}$} & $\mathrm{ND} / \mathrm{NCE}$ & & 0.627 & & \\
\hline & HND/B.Sc/BLS & 0.352 & 0.719 & & \\
\hline & PGD/Masters & & 0.741 & & \\
\hline & $\mathrm{PhD}$ & & & & \\
\hline Designation & $\begin{array}{l}\text { Professional librarians } \\
\text { Paraprofessional }\end{array}$ & 0.391 & 0.800 & & \\
\hline Marital Status & $\begin{array}{l}\text { Married } \\
\text { Single }\end{array}$ & 0.900 & 0.808 & & \\
\hline
\end{tabular}

DEPENDENT VARIABLE: Academic workload stress

PREDICTORS: University type, gender, section, highest educational qualification, Designation, marital status

REFERENCE CATEGORIES: state, female, references, $\mathrm{PhD}$, paraprofessional and single

Source: Research Output (2020)

The relationship between demographic factors and academic workload stress among library personnel in public universities in South-West, Nigeria, was presented in Table 4.4. The finding revealed that gender was the only demographic factor connected to the experience of academic workload stress the Librarians ( $\mathrm{O} . \mathrm{R}=1.157, p<0.05)$. This implies that the likelihood of experiencing academic workload stress tends to be higher among male librarians than their female colleagues at a significant level of $5 \%$. However, university type $(p>0.05)$, section $(p>0.05)$, highest educational qualification $(p>0.05)$, designation $(p>0.05)$ and marital status $(p>0.05)$ were not associated with the experience of academic workload stress among librarians in the public universities at $5 \%$ level of significance. By implication, the gender of librarians deserves adequate attention from the human resource department of libraries in public universities, South-West, Nigeria.

Library and Information Perspectives and Research, Volume 2 Number 1, 2020 
Omobola Olufunke Adewoyin, Maria Ehioghae and Joseph Olubunmi Olorunsaye: Occupational stress among library personnel in public universities in Nigeria

Table 5: Poisson regression analysis of factors associated with research and career development stress

\begin{tabular}{|c|c|c|c|c|c|}
\hline Predictors & Categories & $p$ & $\begin{array}{l}\text { Odds } \\
\text { Ratio }\end{array}$ & LR Stat & $\mathbf{p}$ \\
\hline & (Intercept) & 0.000 & 26.918 & & \\
\hline \multirow[t]{2}{*}{ University type } & Federal & 0.322 & 0.970 & & \\
\hline & State & & & & \\
\hline \multirow[t]{3}{*}{ Gender } & Male & $0.028 *$ & 1.068 & & \\
\hline & Female & & & & \\
\hline & Serials & & 1.152 & & \\
\hline \multirow{5}{*}{ Section } & Acquisitions & & 1.164 & & \\
\hline & Circulation & 0.263 & 1.108 & & \\
\hline & Technical services & & 1.074 & & \\
\hline & Reader services & & 1.115 & & \\
\hline & References & & & 39.601 & 0.000 \\
\hline \multirow{4}{*}{$\begin{array}{l}\text { Highest educational } \\
\text { qualification }\end{array}$} & $\mathrm{ND} / \mathrm{NCE}$ & & 0.846 & & \\
\hline & HND/B.Sc/BLS & $0.026^{*}$ & 0.916 & & \\
\hline & PGD/Masters & & 0.900 & & \\
\hline & $\mathrm{PhD}$ & & & & \\
\hline \multirow[t]{2}{*}{ Designation } & Professional librarians & & 1.091 & & \\
\hline & Para-professional & $0.020 *$ & & & \\
\hline \multirow[t]{2}{*}{ Marital Status } & Married & 0.208 & 1.073 & & \\
\hline & Single & & & & \\
\hline
\end{tabular}

Factors associated with research and career development stress among library personnel in public universities in South-West, Nigeria, were presented in Table 5 . The finding revealed that male librarians are more likely to experience research and career development stress than female librarians $\quad(\mathrm{O} . \mathrm{R}=1.068, \quad p<0.05)$ at $\mathrm{a}$ significant level of 5\%. By implication, gender is significantly associated with research and career development stressamong library personnel. Additionally, librarians with degrees in $\mathrm{ND} / \mathrm{NCE}$ (O.R=0.846), HND/B.Sc/BLS (O.R=0.916) and $\mathrm{PGD} /$ Masters $(\mathrm{O} . \mathrm{R}=0.900)$ were less likely to experience research and career development stress than their colleagues with $\mathrm{PhD}$ certificates, at a significant level of $5 \%$. This implies that educational status is a significant predictor of research and career development stressamong library personnel in public universities in South-West, Nigeria. More so, professional librarians (O.R=1.091, $p<0.05)$ were more likely to experience a higher level of research and career development stress than nonprofessional librarians. By implication, professional designation significantly contributes to occupational stress in public libraries. On the other hand, university type $(p>0.05)$, librarian section $(p>0.05)$ and marital status $(p>0.05)$ did not predict occupational stress among the librarians. The L-R Stat value of $39.601 \quad(p<0.05)$ established the reliability of the Poisson regression model in estimating the influence of demographic factors on research and

Library and Information Perspectives and Research, Volume 2 Number 1, 2020 
Omobola Olufunke Adewoyin, Maria Ehioghae and Joseph Olubunmi Olorunsaye: Occupational stress among library personnel in public universities in Nigeria

career development stress among librarians in the public libraries.

Table 6: Poisson regression analysis of factors associated with interpersonal relationship stress

\begin{tabular}{|c|c|c|c|c|c|}
\hline Predictors & Categories & $P$ & $\begin{array}{l}\text { Odds } \\
\text { Ratio }\end{array}$ & LR Stat & $\mathbf{P}$ \\
\hline & (Intercept) & 0.000 & 10.170 & & \\
\hline \multirow[t]{2}{*}{ University type } & Federal & 0.001 & 1.157 & & \\
\hline & State & & & & \\
\hline \multirow[t]{2}{*}{ Gender } & Male & 0.000 & 1.161 & & \\
\hline & Female & & & & \\
\hline \multirow[t]{5}{*}{ Section } & Acquisitions & & 0.826 & & \\
\hline & Circulation & 0.103 & 0.908 & & \\
\hline & Technical services & & 1.014 & & \\
\hline & Reader services & & 0.912 & & \\
\hline & References & & & 42.021 & 0.000 \\
\hline \multirow{3}{*}{$\begin{array}{l}\text { Highest educational } \\
\text { qualification }\end{array}$} & ND/NCE & & 1.133 & & \\
\hline & HND/BSc/BLS & 0.118 & 1.200 & & \\
\hline & PGD/Masters & & 1.0084 & & \\
\hline \multirow{2}{*}{ Designation } & Professional & & 1.091 & & \\
\hline & librarians & 0.100 & & & \\
\hline Marital Status & $\begin{array}{l}\text { Para-professional } \\
\text { Married } \\
\text { Single }\end{array}$ & 0.624 & 0.962 & & \\
\hline
\end{tabular}

DEPENDENT VARIABLE: Interpersonal relationship stress

PREDICTORS: University type, gender, section, highest educational qualification, Designation, marital status

REFERENCE CATEGORIES: state, female, references, $\mathrm{PhD}$, para-professional and single

Factors connected to interpersonal relationship stress among library personnel in public universities in South-West, Nigeria, were presented in Table 6 . The finding revealed that librarians in federal universities (O.R=1.157, $p<0.05)$ are more likely to experience interpersonal relationship stressthan their counterparts in state universities at 5\% significant level. By implication, university type increases the likelihood of interpersonal relationship stress among library personnel. Also, gender was significantly associated with interpersonal relationship stressamong library personnel. This signifies that interpersonal relationship stress is higher among male librarians $(\mathrm{O} . \mathrm{R}=1.161, p<0.05)$ than their female counterparts. On the other hand, section $(p>0.05)$, highest educational qualification $(p>0.05)$, designation $(p>0.05)$ and marital status $(p>0.05)$ are not associated with interpersonal relationship stress among library personnel in public universities. The L-R Stat value of 42.021 $(p<0.05)$ established the dependability of the

Library and Information Perspectives and Research, Volume 2 Number 1, 2020 
Omobola Olufunke Adewoyin, Maria Ehioghae and Joseph Olubunmi Olorunsaye: Occupational stress among library personnel in public universities in Nigeria

Poisson regression model in estimating the interpersonal relationship stressamong influence of demographic factors on librarians in the public libraries.

Table 7: Poisson regression analysis for factors associated with administrative related stress

\begin{tabular}{|c|c|c|c|c|c|}
\hline Predictors & Categories & $P$ & $\begin{array}{l}\text { Odds } \\
\text { Ratio }\end{array}$ & LR Stat & $\mathbf{P}$ \\
\hline & (Intercept) & 0.000 & 9.557 & & \\
\hline University type & Federal & 0.072 & 1.102 & & \\
\hline & State & & & & \\
\hline Gender & Male & 0.004 & 1.165 & & \\
\hline & Female & $*$ & & & \\
\hline & Serials & & 1.020 & & \\
\hline Section & Acquisitions & & 0.939 & & \\
\hline & Circulation & 0.430 & 1.092 & & \\
\hline & Technical services & & 1.122 & & \\
\hline & Reader services & & 1.101 & & \\
\hline & References & & & 20.736 & 0.005 \\
\hline Highest educational & ND/NCE & & 0.667 & & \\
\hline qualification & HND/B.Sc/BLS & 0.198 & 0.766 & & \\
\hline & PGD/Masters & & 0.745 & & \\
\hline & $\mathrm{PhD}$ & & & & \\
\hline Designation & Professional & 0.761 & 0.860 & & \\
\hline & librarians & & & & \\
\hline & Paraprofessional & & & & \\
\hline Marital Status & Married & 0.435 & 0.768 & & \\
\hline & Single & & & & \\
\hline
\end{tabular}

DEPENDENT VARIABLE: Administrated related stress

PREDICTORS: University type, gender, section, highest educational qualification, Designation, marital status

REFERENCE CATEGORIES: state, female, references, $\mathrm{PhD}$, paraprofessional and single

The relationship between administrative related stress and demographic factors among library personnel in public universities in South-West, Nigeria, was presented in Table 7 . The finding revealed that gender was significantly associated with administrated related stressamong library personnel $(p<0.05)$. By implication, male librarians $(\mathrm{O} . \mathrm{R}=1.161)$ experienced more administrative related stress than their female counterparts. On the other hand, university type $(p>0.05)$, section $(p>0.05)$, highest educational qualification $(p>0.05)$, designation $(p>0.05)$ and marital status $(p>0.05)$ did not predict administrative related stress among librarians in public universities. The L-R Stat value of 20.736 $(p<0.05)$ established the reliability of the Poisson regression model in estimating the influence of demographic factors on administrated related stress among librarians in the public libraries.

Library and Information Perspectives and Research, Volume 2 Number 1, 2020 
Omobola Olufunke Adewoyin, Maria Ehioghae and Joseph Olubunmi Olorunsaye: Occupational stress among library personnel in public universities in Nigeria

\section{Discussion}

As revealed in the findings it is clear that occupational stress is higher among professional librarians than paraprofessional librarians in southwest Nigerian public universities. This is in congruence with studies earlier carried out by Oghenetega, Ejedafiru and Rabiu (2014) that revealed that occupational stress is high in academic libraries. The study indicates that the high level of stress among professional librarians could have a negative impact on their health as well as on the wellbeing of their families. Similarly, Dina (2016) concluded that excessive occupation-related stress leads to a decrease in the quality of service delivery in academic libraries. There is a convergence of research findings that there is enormous stress among professional libraries (Bharathi \& Gupta, 2017; Isiakpona \& Adebayo, 2011; Sampson \& Akyeampong, 2014). But this study reveals that the male professional library staff are more affected by the negative fall-outs of excessive stress than their female counterparts.

Specifically, this study showed that the preponderance of stress among academic library personnel is more pronounced in the area of research and career development. The "publish or perish" syndrome could take its toll on academic librarians because their promotion, among other requirements, is based on the level of research outputs. The problem is compounded by the inability of many professional librarians to source for research funds or grants. This could lead to frustration and stress. Oghenetega, Ejedafiru and Rabiu (2014) corroborated the findings in this study by pointing out the frustration experienced by academic librarians because of poor remunerations. They are unable to finance their research projects that could lead to their career advancement.
Workload has also been implicated in this study for the stress experienced by professional librarians. In line with previous studies, this finding revealed that many academic librarians are saddled with too heavy workloads ( Dina, 2016; Oghenetega, Ejedafiru \& Rabiu, 2014). It is often the case that they are expected to carry out administrative responsibilities involving frequent meetings, aside from teaching and project supervisory demands. Also, in this study, the stress associated with interpersonal relationships was shown to be a factor in the occupational stress of professional librarians. This finding is corroborated by other researchers who concluded that interpersonal relationship is a major predictor of stress generally and particularly in the work environment (Ajala, 2011; Divakar, 2015). Relationship in the workplace is multi-dimensional. In the case of academic library professionals, it includes colleagues, supervisors/supervisees, students, and university management. A ruptured relationship in any of these dimensions could lead to stress.

The Poisson regression analysis on demographics in the study revealed that factors such as gender, academic qualifications, and professionalism were significantly associated with occupational stress. Specifically, professional male librarians with $\mathrm{PhDs}$ are more likely to experience stress as opposed to other library staff. Also, male librarians experience stress associated with academic workload more than their female counterparts, implying that gender is an issue in matters relating to assigning workloads in the academic library. Similarly, demographic factors such as gender and educational type affect interpersonal relationships. As revealed in the analysis, male librarians are more likely to have interpersonal relationship challenges

Library and Information Perspectives and Research, Volume 2 Number 1, 2020 
Omobola Olufunke Adewoyin, Maria Ehioghae and Joseph Olubunmi Olorunsaye: Occupational stress among library personnel in public universities in Nigeria

that their female counterparts. Professional librarians in federal universities were also implicated as having more stress than those working in the state universities. The findings from the analysis show that occupational stress in academic libraries is related to demographic factors such as gender, workloads, academic qualifications, and university type, that is, whether it is federal or state.

\section{Conclusion}

Occupational stress among librarians in federal and state-owned universities impinge on their service delivery. Aside from demographic factors such as gender, academic qualifications and professional status, other critical factors that could exacerbate stress among library professionals include lack of access to funds for professional development, the quest for promotion, excessive workloads, and multifaceted dysfunctional interpersonal relationships that cut across students, supervisees/supervisors, colleagues, and management. Failing to address these challenges may compromise the commitment and productivity of professional and para-professional librarians. Therefore, the following recommendations are proffered:

1. The management of academic libraries in federal and state universities should ensure that library personnel librarians are not saddled with too many responsibilities to prevent excessive stress. Gender balance is necessary for assigning responsibilities.

2. Since promotion for professional librarians is predicated on publications, university management should facilitate access to research grants by either direct funding or creating a platform for accessing such grants. Career development is necessary not only for self-fulfillment but may also reduce the incidence of stressinduced frustrations.

3. Both intra-personal and interpersonal relationships should be improved for professional and non-professional librarians. This may necessitate interpersonal relationship workshops that will promote collegiality and team spirit among students, staff, and management.

\section{References}

Aderibigbe O. \& Farouk B. (2017). Challenges on Marketing of Information Resources and Services in Federal University Libraries in North-West Zone of Nigeria. Inter. J. Acad. Lib. Info. Sci., 5(3): 92-96

Ahmad, S. \&Roslan, N. (2016). Relationship between job stress and organizational commitment among public servants in pontian, Johor. International Journal of Business, Economics and Law, 10(2), 1-7.

Ajala, E. B. (2011). Work-related Stress among Librarians and Information Professionals in a Nigerian University. Library Philosophy and Practice (ejournal). $\quad 450$. https://digitalcommons.unl.edu/li bphilprac/450

Akinmayowa, J. T. (2014). Stress among academic staff in a Nigerian university. Covenant Journal of Business and Social Sciences (CJBSS), 65 (1), 73-91. Arogundade O.\& Onabanjo,O. (2013). Influence of personality and selfesteem on teachers' burnout syndrome in Lagos Metropolis. America Journal of Applied Psychology, 1(1), 7-13.

Library and Information Perspectives and Research, Volume 2 Number 1, 2020 
Omobola Olufunke Adewoyin, Maria Ehioghae and Joseph Olubunmi Olorunsaye: Occupational stress among library personnel in public universities in Nigeria

Bharathi, T and Gupta, K.S., (2017). A Study on Job Stress and Its Influence on the Productivity Among Women Employees in IT Sector. SAGAR International Journal of Management and Research. Available at SSRN: https://ssrn.com/abstract=310447 4

Bhatti,M.,Akram,M., $\quad$ Hashim,M., Akram,M. \& Akram, Z. (2016). Relationship between job stress and organizational commitment: An empirical study of banking sector. Journal of Business Management and Economics, 7(1), 29-37.

Cable, D. M., \&DeRue, D. S. (2002). The convergent and discriminant validity of subjective fit perceptions. Journal of Applied Psychology, 87(5), 875-884.

Cooper, C.L., Dewe, P. \& O'Driscoll, M.P. (2001).Organizational stress: A review and critique of theory, research, and applications. Thousand Oaks: Sage.

Dina, T. (2016). The effect of stress on professional librarians job performance in Nigerian university libraries. Library Philosophy and Practice (EJournal). 431. Http://Digitalcommons.Unl.Edu/ Libphilprac/1431

Divakar, J. B. (2015). Factors leading to work stress and its impact on employee performance - A case study of reliance fresh, India. Dissertation submitted in part fulfilment of the requirements for the degree of International Masters in Business Administration at Dublin
Business School and Liverpool John Moore's University.

Edwards, J. R., Caplan, R. D., \& Harrison, R. V. (1998). Personenvironment fit theory: Conceptual foundations, empirical evidence, and directions for future research. In C. L. Cooper (Ed.), Theories of organizational stress (pp. 2867). Oxford: Oxford University Press.

Ella, R.E. Asuquo, E.F. Akpan-Idiok, P.A. \& Ijabula, J. (2016).Impact of job stress on nurses' job satisfaction in a public hospital, Cross River State, Calabar, Nigeria. International Journal of Humanities Social Sciences and Education (IJHSSE), 3 (9), 5766.

Ikonne, C. (2015) Job stress and pyschological well-being among library employees: a survey of library staff in selected university libraries in SouthWest Nigeria. Open Access Library Journal, 2, 1-12. doi: 10.4236/oalib.1101632.

Isiakpona, C. \& Adebayo, O. (2011). The Impact of Technostress on Librarians: A Survey of Covenant University Library. The Information Manager, 11 (1\&2), 56-61.

Joseph, T. (2013). Work-related stress. European Journal of Business and Social Science. 1(10), 73-80.

Leka, S., Griffiths, A., Cox, T. (2003). Work organisation and stress : systematic problem approaches for employers, managers and trade union representatives. World Health Organization.

Library and Information Perspectives and Research, Volume 2 Number 1, 2020 
Omobola Olufunke Adewoyin, Maria Ehioghae and Joseph Olubunmi Olorunsaye: Occupational stress among library personnel in public universities in Nigeria

https://apps.who.int/iris/handle/1 0665/42625

Oghenetega, L. U., Ejedafiru, E. F. \& Rabiu, A. M. (2014). Comparative study of job stress among teaching staff of library and information science in higher institutions in Nigeria. Journal of Education and Practice, 5 (16), 213-220.

Okoro, E. (2018). Assessment of stress related issues and coping mechanisms among college students. All Theses, Dissertations, and Other Capstone Projects. 825.https://cornerstone.lib.mnsu. edu/etds/825.

Sampson, W. G., \&Akyeampong, O. (2014). Work-related Stress in Hotels: An Analysis of the Causes and Effects among Frontline Hotel Employees in the Kumasi Metropolis, Ghana. J Tourism Hospit,3, 127. doi:10.4172/2167-0269.100012.

The World Health Report. Accessed July 4, $2020 \quad$ at https://www.who.int/whr/2003/e n/whr03_en.pdf.

\begin{abstract}
About the authors
Omobola Olufunke Adewoyin is currently a deputy director in the Department of Library and Information Communication Technology, Nigerian Institute of Medical Research, Nigeria. She holds a Master of Philosophy degree from the Department of Information Resources Management, Babcock University, Nigeria. She also holds MHIM and MLS degrees from the University of Ibadan. She is a member of the Medical Library Associationand a member of Nigerian Library Association (NLA), Nigeria. She is a chartered librarian. Her
\end{abstract}

research interests are social media and library management. +234 8060518616; Email: adewoyinomobola@yahoo.com

Maria Ehioghae is the Medical Librarian of Benjamin Carson Sr School of Medicine Library, Ilishan-Remo, Ogun State, Nigeria. She holds a Bachelor's degree in Information Resources Management (BIRM) and a Masters' degree in Information Resources Management (MIRM), Babcock University, IlishanRemo, Ogun State, Nigeria. She is a member of both the Medical Library Association, Nigeria (MLA-NG) and the Nigerian Library Association (NLA), Nigeria. Her area of specialization is in health information management in librarianship. She may be reached at the following contacts: +234 7034728537; E-mail: ehioghaem@babcock. edu.ng.

Joseph Olubunmi Olorunsaye is the Head, Collection Development and Acquisitions units, Kenneth Dike Library, University of Ibadan. A Chartered Librarian and two-term Chairman of Nigerian Library Association Oyo State Chapter. He bagged his Bachelor's degree in Library and Information Studies (BLIS) and Masters's degree in Library, Archival and Information Science (MLAIS), University of Ibadan, Ibadan, Nigeria. His area of specialization is Information Communication Technology, Information Literacy, Library Management System, Cataloguing and Classification and Medical Librarianship. His contacts are: +234-8166552100; E-mail: jo.olorunsaye @mail1.ui.edu.ng, orolorunsaye2004@gm ail.com. 